\title{
COMPARISON BETWEEN TWO FEEDING RATES AND THREE FEEDING FREQUENCIES FOR HYBRID SURUBIMS REARED IN CAGES ${ }^{1}$
}

\author{
JULIANA SVERSUT DE ALEXANDRE BOGIANI ${ }^{2}$, CECÍLIA SILVA DE CASTRO ${ }^{3 *}$, EDUARDO MIYAMOTO \\ FUKANOKI KUNII $^{4}$, LUCIANO CAETANO DE OLIVEIRA ${ }^{3}$, CLAUDIO ANGELO AGOSTINHO 5
}

\begin{abstract}
This study evaluated the effects of feeding frequency and feeding rate on productive performance of hybrid surubims reared in cages with automatic feeding. Three feeding frequencies $(6,12$ and 24 meals day $\left.{ }^{-1}\right)$, and two feeding rates ( $4 \%$ and $8 \%$ of body weight per day, BW day ${ }^{-1}$ ) were evaluated. Hybrid surubims (Pseudoplatystoma corruscans $\times$ Pseudoplatystoma fasciatum) with average weights of $24.20 \pm 0.80$ $\mathrm{g}$ were distributed in 18 cages of $1.0 \mathrm{~m}^{3}$ at a density of 60 fish $\mathrm{m}^{-3}$. Fish were fed commercial ration containing $40 \%$ crude protein, and feeding took place at night using automatic feeders. The study lasted 47 days. With a feeding rate of $4 \% \mathrm{BW}$ day $^{-1}$, the final weight (FW) of the surubims was higher when feed was supplied as 24 meals day ${ }^{-1}(66.92 \mathrm{~g})$. However, using $8 \% \mathrm{BW} \mathrm{day}^{-1}$, the $\mathrm{FW}$ was greater with a feeding frequency of 12 meals $\operatorname{day}^{-1}(106.90 \mathrm{~g})$. Regardless of feed frequency, the values of daily weight gain and standard length of surubims were higher with the feeding rate of $8 \% \mathrm{BW}_{\text {day }^{-1}}$. Therefore, the feeding rate of $8 \% \mathrm{BW}_{\text {day }}{ }^{-1}$, provided in 12 meals day ${ }^{-1}$, provided better productive performance for hybrid surubims (Pseudoplatystoma corruscans $\times$ Pseudoplatystoma fasciatum) reared in cages.
\end{abstract}

Keywords: Feed management. Nocturnal feeding. Pseudoplatystoma corruscans. Pseudoplatystoma fasciatum.

\section{COMPARAÇÃO ENTRE DUAS TAXAS E TRÊS FREQUÊNCIAS ALIMENTARES PARA SURUBINS HÍBRIDOS CRIADOS EM TANQUE REDE}

\begin{abstract}
RESUMO - Este estudo avaliou os efeitos da frequência e taxa de alimentação sobre o desempenho produtivo de surubins híbridos criados em tanque rede. Três frequências $\left(6,12\right.$ e 24 refeições dia $\left.{ }^{-1}\right)$ e duas taxas de alimentação ( $4 \%$ e $8 \%$ do peso vivo por dia, PV dia $^{-1}$ ) foram avaliadas. Híbridos de surubim (Pseudoplatystoma corruscans x Pseudoplatystoma fasciatum), com peso médio de 24,20 $\pm 0,80 \mathrm{~g}$, foram distribuídos em 18 tanques rede de $1,0 \mathrm{~m}^{3}$ com densidade de 60 peixes $\mathrm{m}^{-3}$. Os peixes foram alimentados no período noturno por alimentadores automáticos, com ração comercial contendo $40 \%$ de proteína bruta. O estudo teve duração de 47 dias. Com a frequência de $4 \% \mathrm{PV} \mathrm{dia}^{-1}$, o peso final (PF) dos surubins foi maior com o fornecimento da ração em 24 refeições dia ${ }^{-1}(66,92 \mathrm{~g})$. Entretanto, usando $8 \% \mathrm{PV} \mathrm{dia}^{-1}$ o PF foi maior com a frequência de 12 refeições dia $^{-1}(106,90 \mathrm{~g})$. Independente da frequência alimentar, os valores de ganho de peso diário e comprimento padrão dos surubins foram maiores com a taxa de alimentação de $8 \% \mathrm{PV} \mathrm{dia}^{-1}$. Assim, o fornecimento da ração com taxa alimentar de $8 \% \mathrm{PV} \mathrm{dia}^{-1}$, dividida em 12 refeições dia ${ }^{-1}$, proporcionou melhor desempenho produtivo para surubins híbridos (Pseudoplatystoma corruscans $\times$ Pseudoplatystoma fasciatum) criados em tanque rede.
\end{abstract}

Palavras-chave: Manejo alimentar. Alimentação noturna. Pseudoplatystoma corruscans. Pseudoplatystoma fasciatum.

\footnotetext{
${ }^{*}$ Corresponding author

${ }^{1}$ Received for publication in 06/30/2016; accepted in 09/06/2017.

Paper extracted from the master dissertation of the first author.

${ }^{2}$ Suple-Sal, Araçatuba, SP, Brazil; jusversut@hotmail.com - ORCID: 0000-0003-4143-4860.

${ }^{3}$ Postgraduate Program in Aquaculture and Sustainable Development, Universidade Federal do Paraná, Palotina, PR, Brazil; cica_silva@hotmail.com - ORCID: 0000-0002-2871-6161, lucianocaetano@ufpr.br - ORCID: 0000-0002-6642-870X.

${ }^{4}$ Empório Aquático, São Paulo, SP, Brazil; edukunii@yahoo.com.br - ORCID: 0000-0001-7346-631X.

${ }^{5}$ Postgraduate Program in Zootechny, Faculdade de Medicina Veterinária e Zootecnia, Universidade Estadual Paulista, Botucatu, SP, Brazil; agostinho@fmvz.unesp.br - ORCID: 0000-0003-0355-0553.
} 


\section{INTRODUCTION}

Surubims (Pseudoplatystoma spp.) are freshwater fish that have good meat quality and are considered highly valuable fish in Brazil (INOUE et al., 2009). The Pseudoplatystoma genus has three species: P. corruscans, native to the Paraná basin and São Francisco; P. fasciatum, present in the basins of Paraná and Amazon; and $P$. tigrinum, native to the Amazon basin (BALDISSEROTO; GOMES, 2005). The strain usually marketed is the hybrid between $P$. corruscans $\times$ P. fasciatum (CREPALDI et al., 2006).

Since the 2000 s, the use of hybrids in fish farming has received special attention, as hybridization may be used in order to take advantage of the favorable characteristics of the parental species, as well as improving performance of fish reared in captivity (FAUSTINO et al., 2007). The optimization of feed management techniques is important in order to be able to take full advantage of the potential growth of hybrid strains. According to Schnaittacher, King and Berlinsky (2005), optimizing feed management strategies in fish production is important for maximizing growth, improving feed conversion, minimizing heterogeneity and decreasing feed wastage.

Knowledge of which feeding frequency and feeding period (day, night or day/night) is more suitable contributes to better use of feed, and to the improvement of production efficiency (CASTRO et al., 2014). The feeding frequency represents how often fish are fed in a specific period of time and is vital for the establishment of an adequate feed management program (MIZANUR; BAI, 2014). The use of high feeding frequency in fish production, that is, greater division of the diet with greater distribution throughout the day or night, has been shown to contribute to improved growth and feed efficiency (ZHOU et al., 2003; SOUSA et al., 2012), and decreased heterogeneity (WANG; HAYWARD; NOLTIE, 1998; XIE et al., 2011), as well as improving the water quality in intensive rearing systems (PHILLIPS; SUMMERFELT; CLAYTON, 1998).

In addition to the feeding frequency and feeding period, the amount of food supplied daily should be considered. The feeding rate represents the amount of food per fish per day, and its optimization is crucial for the success of any aquaculture practice (MARIMUTHU et al., 2011; MIZANUR; BAI, 2014). According to Cho et al. (2003), excess feeding can increase the cost of production due to high costs of feed, and cause deterioration of water quality, which can eventually reduce fish growth. On the other hand, feeding below the optimal amount for fish growth is undesirable.

Carnivorous fish, such as surubims, have a greater capacity for food intake (TUCKER; ROBINSON, 1991) and may have better productive performance when fed at higher feeding rates.
However, depending on how often the food is supplied, high feeding rates can become excessive and increase the rate of passage of food in the gastrointestinal tract (STOREBAKKEN et al., 1999; ROTTA, 2003). Higher feeding frequencies can improve the use of diet when feed is supplied a high feeding rate (OLIVEIRA et al., 2016). Therefore, the aim of this study was to evaluate the effects of two feeding rates, one close to what is usually offered in commercial fish farms of surubims ( $4 \%$ of body weight per day), and another above this value ( $8 \%$ of body weight per day), divided into 6,12 or 24 meals day ${ }^{-1}$, on productive performance of hybrid surubims reared in cages with automatic feeding.

\section{MATERIAL AND METHODS}

Eighteen net cages with dimensions of $1.0 \times 1.0 \times 1.0 \mathrm{~m}\left(1.0 \mathrm{~m}^{3}\right)$ were used in this experiment for rearing the surubims. The cages were distributed linearly in a $2000 \mathrm{~m}^{2}$ pond with average depth of two meters and daily water renewal of 60 liters minute $^{-1}$. The average water temperature was $27.89 \pm 0.80^{\circ} \mathrm{C}$, dissolved oxygen ranged between 4.65 and $5.77 \mathrm{mg} \mathrm{L}^{-1}$, and the average $\mathrm{pH}$ was $7.38 \pm 0.04$ during the study. The $\mathrm{pH}$ (measured with an Oakton electrode), temperature, and dissolved oxygen (measured with a YSI55 oximeter) were monitored daily in the morning, at three distinct points of the pond. One automatic feeder (AGOSTINHO et al., 2010) was installed in each cage for supplying feed. The automatic feeder used an electric motor to dispense the feed, and a timer to set the operating time, which makes it possible to predetermine the feeding period, feeding frequency and the quantity supplied at each meal.

Hybrid surubims (Pseudoplatystoma corruscans $\times$ Pseudoplatystoma fasciatum), with average weights of $24.2 \pm 0.8 \mathrm{~g}$ were distributed in the net cages at a density of 60 fish $\mathrm{m}^{-3}$. The fish were acquired from the Mar \& Terra fish farm in Bandeirantes, Mato Grosso do Sul, Brazil. The experimental design was completely randomized with treatments arranged in a factorial design, and three feeding frequencies $\left(6,12\right.$ and 24 meals day $\left.{ }^{-1}\right)$ and two feeding rates $(4 \%$ and $8 \%$ of body weight per day, BW day ${ }^{-1}$ ) were tested, with three replications per treatment. At the beginning of the experiment all fish were anesthetized with eugenol (VIDAL et al., 2006) and individually weighed and measured. At 22 days, a sample of $16 \%$ of the fish from each experimental unit was individually weighed to adjust the amount of feed supplied according to the weight of the animals in each treatment.

The surubims were fed at night (18h to $6 \mathrm{~h}$ ), due to the feeding habits of this species. The feed management implemented through automatic feeders (AGOSTINHO et al., 2010), with extruded 
commercial ration for carnivorous fish containing, according to the manufacturer, $40 \%$ crude protein, $10 \%$ moisture, $10 \%$ lipid, $6 \%$ crude fiber and $13 \%$ mineral matter. The feeding was divided in accordance with the feeding frequency and supplied in equal portions at each meal. For the 24 meals day $^{-1}$ treatment, the rations were supplied at $30 \mathrm{~min}$ intervals, the 12 meals day ${ }^{-1}$ at 60 min intervals, and the 6 meals day ${ }^{-1}$ at 2 hour intervals. The experiment lasted 47 days.

At the end of the experiment, all the fish of each experimental unit were anesthetized with eugenol (50 $\left.\mathrm{mg} \mathrm{L}^{-1}\right)$, according to Vidal et al. (2006), and individually weighed and measured. The productive performance of surubims was evaluated through the following indexes: final weight, FW (g); daily weight gain, DWG $(\mathrm{g})=$ (final weight - initial weight)/days of rearing; apparent feed conversion, $\mathrm{AFC}=$ feed offered $(\mathrm{g}) /$ total weight gain $(\mathrm{g})$, and standard length, SL (cm). The apparent feed conversion rate was calculated based on the amount of food supplied, and the leftovers were not considered. To compute this, all the feed placed in the automatic feeders at the beginning of the experiment were weighed and recorded, and the same procedure was done until the end of the experiment.

The data of productive performance were evaluated by analysis of variance (ANOVA) through the System for Statistical Analyses and Genetics - SAEG (EUCLYDES, 2005). The model included the effects of feeding rate, feeding frequency and the interaction between them, and the averages were compared by Duncan's test at 5\% probability. The homoscedasticity of variances (Levene's test) and normality of the data distribution (Shapiro-Wilk test) were verified.

\section{RESULTS AND DISCUSSION}

There was a significant interaction effect of feeding rate and feeding frequency only on the average values of final weight (FW). Surubims fed at a feeding rate of $4 \% \mathrm{BW}$ day $^{-1}$ had better growth with more frequent feeding, with higher values of FW for the frequency of 24 meals day ${ }^{-1}$ (Table 1). Regardless of feeding rate, the standard length of fish was higher with this feeding frequency (Table 2 ). These results are consistent with those obtained by several authors, who observed improvements in productive performance with increasing feeding frequency in different species of fish (ZHOU et al., 2003; TÜRKER; YILDIRIM, 2011; XIE et al., 2011; SOUSA et al., 2012; FERDOUS et al., 2014). According Sousa et al. (2013), the most frequent feeding improves food utilization and consequently the growth of fish. However, when the feed was supplied as a greater proportion of body weight $(8 \%$ BW day $^{-1}$ ), fish growth was not better with use of the higher feeding frequency, and in this case the frequency of 12 meals day $^{-1}$ was the most appropriate compared to the other frequencies tested (Table 1).

Table 1. Average values and standard deviations of final weight (FW) of hybrid surubims subjected to different feeding rates and feeding frequencies for 47 days.

\begin{tabular}{lrr}
\hline \multirow{2}{*}{ Feeding Frequency $\left(\right.$ meals day $\left.^{-1}\right)$} & \multicolumn{2}{c}{ Feeding rate } \\
\cline { 2 - 3 } & & \\
\hline$F W(g)$ & & $8 \%$ BW day $^{-1}$ \\
24 & $66.92 \pm 6.27 \mathrm{bA}$ & $98.40 \pm 8.79 \mathrm{aB}$ \\
12 & $59.07 \pm 5.94 \mathrm{bB}$ & $106.90 \pm 6.91 \mathrm{aA}$ \\
6 & $60.30 \pm 1.60 \mathrm{bB}$ & $98.13 \pm 16.78 \mathrm{aB}$ \\
\hline
\end{tabular}

Means followed by the same letter, lowercase (in the line) and uppercase (in the column), do not differ by Duncan test $(\mathrm{P}<0.05)$; BW, body weight.

Surubims are fish of carnivorous habits, which gives this species the ability to ingest large amounts of food in one meal (TUCKER; ROBINSON, 1991), with large food storage capacity in the stomach. Thus, with the feeding rate of $8 \%$ BW day ${ }^{-1}$ the frequency of 24 meals day ${ }^{-1}$ was not the most appropriate for the growth of surubims, probably due to the smaller amount of food supplied per meal, and the feeding rate of 12 meals day ${ }^{-1}$ may have been the ideal limit for storing food, after a few meals, without interfering in its use. The presence of large amounts of feed in the stomach accelerates peristalsis, facilitating emptying (ROTTA, 2003), which may influence the feed digestibility and consequently the productive performance. 
Table 2. Average values and standard deviations of daily weight gain (DWG), apparent feed conversion (AFC) and standard length (SL) of hybrid surubims subjected to different feeding rates and feeding frequencies for 47 days.

\begin{tabular}{|c|c|c|c|}
\hline \multirow{2}{*}{$\begin{array}{l}\text { Feeding Frequency } \\
\quad\left(\text { meals day }^{-1}\right)\end{array}$} & \multicolumn{2}{|c|}{ Feeding rate } & \multirow{2}{*}{ Averages } \\
\hline & $4 \%$ BW day ${ }^{-1}$ & $8 \%$ BW day $^{-1}$ & \\
\hline \multicolumn{4}{|l|}{$D W G(g)$} \\
\hline 24 & $0.91 \pm 0.14$ & $1.58 \pm 0.19$ & $1.24 \pm 0.40 \mathrm{~A}$ \\
\hline 12 & $0.73 \pm 0.11$ & $1.77 \pm 0.16$ & $1.25 \pm 0.53 \mathrm{~A}$ \\
\hline 6 & $0.77 \pm 0.02$ & $1.62 \pm 0.37$ & $1.19 \pm 0.51 \mathrm{~A}$ \\
\hline Averages & $0.80 \pm 0.10 \mathrm{~b}$ & $1.65 \pm 0.28 \mathrm{a}$ & \\
\hline \multicolumn{4}{|l|}{$A F C$} \\
\hline 24 & $1.02 \pm 0.04$ & $1.05 \pm 0.11$ & $1.03 \pm 0.09 \mathrm{~A}$ \\
\hline 12 & $1.01 \pm 0.03$ & $1.11 \pm 0.09$ & $1.06 \pm 0.08 \mathrm{~A}$ \\
\hline 6 & $1.24 \pm 0.27$ & $1.25 \pm 0.15$ & $1.24 \pm 0.21 \mathrm{~A}$ \\
\hline Averages & $1.09 \pm 0.17 \mathrm{a}$ & $1.14 \pm 0.15 \mathrm{a}$ & \\
\hline \multicolumn{4}{|l|}{$S L(\mathrm{~cm})$} \\
\hline 24 & $19.14 \pm 1.07$ & $21.91 \pm 1.34$ & $20.53 \pm 1.84 \mathrm{~A}$ \\
\hline 12 & $17.66 \pm 1.41$ & $21.93 \pm 1.61$ & $19.79 \pm 2.62 \mathrm{~B}$ \\
\hline 6 & $18.05 \pm 1.59$ & $21.12 \pm 1.34$ & $19.59 \pm 2.34 \mathrm{~B}$ \\
\hline Averages & $18.29 \pm 1.57 \mathrm{~b}$ & $21.65 \pm 1.49 \mathrm{a}$ & \\
\hline
\end{tabular}

Means followed by the same letter, lowercase (in the line) and uppercase (in the column), do not differ by Duncan test $(\mathrm{P}<0.05)$; BW, body weight.

The feeding frequency is strongly correlated with gastric evacuation time (RICHE et al., 2004), and the return of appetite is related to the rate of gastric emptying (LEE; HWANG; CHO, 2000). Feeding at intervals shorter than the time required for the return of appetite can lead to gastric overload, resulting in reduced absorption efficiency (RICHE et al., 2004). Therefore, in this study, the time interval between each meal in the feeding frequency of 12 meals day ${ }^{-1}$ (every 1 hour) was the most suitable for hybrid surubims reared in cages with automatic feeding. It is likely that this time interval was sufficient for the return of appetite, and positively influenced productive performance.

The amount of food supplied at each meal is the main limiting factor for fish growth (SILVA; GOMES; BRANDÃO, 2007). According to Trushenski et al. (2012), the increasing of feeding frequency can be beneficial in terms of digestion and absorption efficiency in the productive performance, particularly when high feeding rates are used. The supply of ration with $8 \% \mathrm{BW}$ day $^{-1}$ lead to lower growth of surubims with the division of feeding in 6 meals day ${ }^{-1}$. However, with more frequent feeding $\left(12\right.$ meals day $\left.^{-1}\right)$ the growth of surubims improved with the ration supplied at the rate of $8 \% \mathrm{BW}$ day $^{-1}$. This is consistent with reports by other authors who observed improvement in productive performance of fish when feed rations were supplied at higher feeding rates and higher feeding frequencies (SILVA; GOMES; BRANDÃ̃O, 2007; TRUSHENSKI et al., 2012). According to Oliveira et al. (2016), the subdivision of the daily ration into small portions (high feeding frequency) may decrease the demand for oxygen to metabolize each meal, contributing to a better performance of fish fed with higher feeding rates.

The results of the apparent feed conversion (AFC) were not influenced by the different feeding rates and feeding frequencies (Table 2). The feeding rate of $8 \% \mathrm{BW} \mathrm{day}^{-1}$ is above the quantities normally offered in commercial fish farms of surubims, which offer approximately $5 \%$ of $\mathrm{BW}$ day $^{-1}$ for the growth phase studied. The ration, if supplied in excess, can 
compromise water quality and consequently reduce fish growth (CHO et al., 2003; BISWAS et al., 2006). The AFC results showed that the feeding rate of $8 \% \mathrm{BW}$ day $^{-1}$ was not excessive for the production of surubims because the average values of this parameter, regardless of feeding frequency, were similar to those observed in the treatment where the fish were fed with feeding rate of $4 \% \mathrm{BW}$ day $^{-1}$, with values close to 1.0 , indicating that this high feeding rate did not provide food wastage that compromised the production of surubims. The daily weight gain and standard length were also higher for fish fed with this high feeding rate (Table 2).

\section{CONCLUSIONS}

Supplying feed at a feeding rate of $8 \% \mathrm{BW}$ day $^{-1}$ divided into 12 meals day ${ }^{-1}$ resulted in better productive performance for hybrid surubims (Pseudoplatystoma corruscans $\mathrm{x}$ Pseudoplatystoma fasciatum) reared in cages with automatic feeding.

\section{ACKNOWLEDGMENTS}

The authors would like to thank the Mar \& Terra fish farm in Bandeirantes, Mato Grosso do Sul, Brazil for the fish donated for this study.

\section{REFERENCES}

AGOSTINHO, C. A. et al. Alimentador automático para peixes e organismos aquáticos em geral. INPI Instituto Nacional da Propriedade Industrial, Brasil, (PI10055363, 03 dez. 2010). 2010.

BALDISSEROTO, B.; GOMES, L. C. Espécies nativas para a piscicultura no Brasil. 1. ed. Santa Maria, RS: Editora UFSM, 2005. 470 p.

BISWAS, G. et al. Effect of feeding frequency on growth, survival and feed utilization in mrigal, Cirrhinus mrigala, and rohu, Labeo rohita, during nursery rearing. Aquaculture, Amsterdam, v. 254, n. 1-4, p. 211-218, 2006.

CASTRO, C. S. et al. Feed digestibility and productive performance of bullfrogs raised in cages and fed in different periods and high frequency. Aquaculture, Amsterdam, v. 433, s/n., p. 1-5, 2014.

$\mathrm{CHO}, \mathrm{S} . \mathrm{H}$. et al. Effect of feeding rate and feeding frequency on survival, growth and body composition of Ayu post-larvae Plecoglossus altivelis. Journal of the World Aquaculture Society, Baton Rouge, v. 34, n. 1, p. 85-91, 2003.
CREPALDI, D. V. et al. O surubim na aquacultura do Brasil. Revista Brasileira de Reprodução Animal, Belo Horizonte, v. 30, n. 3-4, p. 150-158, 2006.

EUCLYDES, R. SAEG: sistema para análise estatística e genética. versão 9.0. Viçosa, MG: Universidade Federal de Viçosa, 2005.

FAUSTINO, F. et al. Fertilização e desenvolvimento embrionário: morfometria e análise estereomicroscópica dos ovos dos híbridos de surubins (pintado, Pseudoplatystoma corruscans $\mathrm{x}$ cachara, Pseudoplatystoma fasciatum). Acta Scientiarum Biological Sciences, Maringá, v. 29, n. 1, p. 49-55, 2007.

FERDOUS, Z. et al. Performance of different feeding frequency on growth indices and survival of monosex tilapia, Oreochromis niloticus (Teleostei: Cichlidae) fry. International Journal of Fisheries and Aquatic Studies, New Delhi, v. 1, n. 5, p. 8083, 2014.

INOUE, L. A. K. A. et al. Princípios básicos para produção de alevinos de surubins (pintado e cachara). 1. ed. Dourados, MS: Embrapa Agropecuária Oeste, 2009. 26 p.

LEE, S.; HWANG, U.; CHO, S. H. Effects of feeding frequency and dietary moisture content on growth, body composition and gastric evacuation of juvenile Korean rockfish (Sebastes schlegeli). Aquaculture, Amsterdam, v. 187, n. 3-4, p. 399409,2000

MARIMUTHU, K. et al. Effect of different feed application rate on growth, survival and cannibalism of African catfish, Clarias gariepinus fingerlings. Emirates Journal of Food and Agriculture, Al Ain, v. 23, n. 4, p. 330-337, 2011.

MIZANUR, R. M.; BAI, S. C. A review of the optimum feeding rates and feeding frequency in korean rockfish Sebastes schlegeli reared at seven different water temperatures. Fisheries and Aquatic Sciences, Busan, v. 17, n. 2, p. 229-247, 2014.

OLIVEIRA, F. A. et al. Automatic feeders for Nile tilapia raised in cages: productive performance at high feeding frequencies and different rates. Arquivo Brasileiro de Medicina Veterinária e Zootecnia, Belo Horizonte, v. 68, n. 3, p. 702-708, 2016.

PHILLIPS, T. A.; SUMMERFELT, R. C.; CLAYTON, R. D. Feeding frequency effects on water quality and growth of walleye fingerlings in intensive culture. The Progressive Fish-Culturist, Maryland, v. 60, n. 1, p. 1-8. 1998. 
RICHE, M. et al. Effect of feeding frequency on gastric evacuation and the return of appetite in tilapia Oreochromis niloticus (L.). Aquaculture, Amsterdam, v. 234, n. 1-4, p. 657-673, 2004.

ROTTA, M. A. Aspectos gerais da fisiologia e estrutura do sistema digestivo dos peixes relacionados à piscicultura. 1 . ed. Corumbá, MS: Embrapa Pantanal, 2003. 48 p.

SCHNAITTACHER, G.; KING, W.; BERLINSKY, D. L. The effects of feeding frequency on growth of juvenile Atlantic halibut, Hippoglossus hippoglossus L. Aquaculture Research, Oxford, v. 36, n. 4, p. 370-377, 2005.

SILVA, C. R.; GOMES, L. C.; BRANDÃO, F. R. Effect of feeding rate and frequency on tambaqui (Colossoma macropomum) growth, production and feeding costs during the first growth phase in cages. Aquaculture, Amsterdam, v. 264, n. 1-4, p. 135139, 2007.

SOUSA, R. M. R. et al. Productive performance of Nile tilapia (Oreochromis niloticus) fed at different frequencies and periods with automatic dispenser. Arquivo Brasileiro de Medicina Veterinária e Zootecnia, Belo Horizonte, v. 64, n. 1, p. 192-197, 2012.

SOUSA, R. M. R. et al. Avanço tecnológico na produção brasileira de peixe: utilização de alimentadores automáticos na larvicultura de tilápia. Informe Agropecuário, Belo Horizonte, v. 34, n. 272, p. 76-79, 2013.

STOREBAKKEN, T. et al. Estimation of gastrointestinal evacuation rate in Atlantic salmon (Salmo salar) using inert markers and collection of faeces by sieving: evacuation of diets with fish meal, soybean meal or bacterial meal. Aquaculture, Amsterdam, v. 172, n. 3-4, p. 291-299, 1999.

TRUSHENSKI, J. et al. Feeding rate and frequency affect growth of juvenile Atlantic spadefish. North American Journal of Aquaculture, Maryland, v. 74, n. 1, p. 107-112, 2012.

TUCKER, C. S.; ROBINSON, E. H. Channel catfish farming handbook. New York: AVI Books/ Van Nostrand Reinhold, 1991. 454 p.

TÜRKER, A.; YILDIRIM, O. The effect of feeding frequency on growth performance and body composition in juvenile rainbow trout (Oncorhynchus mykiss) reared in cold seawater. African Journal of Biotechnology, Kenya, v. 10, n. 46, p. 9479-9484, 2011.
VIDAL, L. V. O. et al. Utilização do eugenol como anestésico para o manejo de juvenis de pintado (Pseudoplatystoma corruscans). Acta Scientiarum. Biological Sciences, Maringá, v. 28, n. 3, p. 275279, 2006

WANG, N.; HAYWARD, R. S.; NOLTIE, D. B. Effect of feeding frequency on food consumption, growth, size variation, and feeding pattern of age- 0 hybrid sunfish. Aquaculture, Amsterdam, v. 165, n. 3-4, p. 261-267, 1998.

XIE, F. et al. The optimal feeding frequency of large yellow croaker (Pseudosciaena crocea, Richardson) larvae. Aquaculture, Amsterdam, v. 311, n. 1-4, p. $162-167,2011$.

ZHOU, Z. et al. Effect of feeding frequency on growth, feed utilization, and size variation of juvenile gibel carp (Carassius auratus gibelio). Journal of Applied Ichthyology, Berlin, v. 19, n. 4, p. 244-249, 2003. 